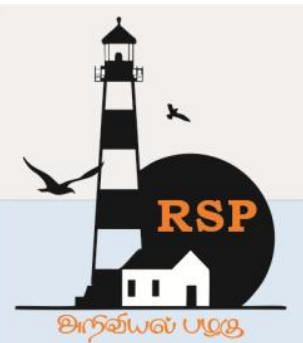

INTERNATIONAL RESEARCH JOURNAL ON ADVANCED SCIENCE HUB

RSP SCIENCE HUB

(The Hub of Research Ideas)

Available online at www.rspsciencehub.com

Special Issue of Second International Conference on Advancements in Research and Development (ICARD 2021)

\title{
Struggle of Agriculturists due to Modern Technology
}

\author{
Sandhya Naveen ${ }^{l}$ \\ ${ }^{1}$ B.Ed trainee, Shree Gokarnanatheshwara College of Education, Mangalore, Karnataka \\ sandhya.padubailu@yahoo.in
}

\begin{abstract}
Farmers are the backbones of our nation. Their field work will reduce the peoples hunger and keeps the land fertile with green environment. At present, most of the traditional techniques of agriculture are replaced by the technologies. Modernization and modification of technology is helped a lot to the people to a maximum extent. Technology has brought up to consume the time and complete the work with less number of workers. Influence of technologies became a big metal ball to the agriculturist having less cultivation land and the small scale agriculturists of rural area. The technology made poor farmers to struggle for the workers. Information technology is speed enough to reach the information to almost all the farmers. As the technology sounded more, the people who were working in fields started turning towards the technology having family as they will get less work. So, poor farmers couldn't fulfil the demands of the workers in different ways. Some of the poor formers gave up the agriculture because of lack of workers. In fact small scales agriculturists are far from the utilization of technology list and their presence are disappeared. Author winded up the study with the highlighting the major problems faced by the small scale agriculturists in rural area. Some possible suggestions are mentioned to overcome from these difficulties to live stress less peaceful life.
\end{abstract}

Keywords: Agriculture, technology, small scale agriculturists, farmers, field workers

\section{Introduction}

Farmers are the backbones of our nation. Farmers can be called as main sources to fulfill the needy food items, help in manufacturing different secondary products as per the timely requirements of living beings. They are contributing more to the Indian economy. For the purpose of attaining essentials of people, farmers were following the traditional methods with help of skilled field workers till the end of $19^{\text {th }}$ century. The traditional method of agriculture was hardworking system which made our elders to be strong, fit and healthy. Actually the field work itself was a good exercise for the farmers. The heavy work and consumption of time has been reduced by the introduction of mechanization at the end of the $19^{\text {th }}$ century. Farmers could witness significant advancements in agro tech in the twentieth century, including the evolution of synthetic fertilizers and pesticides, as well as cutting-edge agricultural machinery such as mass-produced tractors and agricultural aircraft for aerial pesticide application. Agricultural plastics, genetically modified crops, improved drip irrigation, and soilless farming methods such as hydroponics, aquaponics and aeroponics are among the most recent advancements. Digital Age innovations were gradually introduced to agriculture in the early years of the twenty-first century. Agricultural robots, drones, and self-driving tractors have established themselves as permanent fixtures on farms, while digital agriculture and precision agriculture make extensive use of data collection and computation to boost farm productivity [9]. 


\section{Participant and non participant observation} Being a member of farmer's family self experienced the difficulties, problem faced during the farming. There are many farmers in my locality having less cultivation lands. Decades ago the land was cultivated three times in a year, now the farmers are finding difficult to grow the crops even once in a year. The farmers were facing many challenges in different ways. Mainly the lack of field workers, water deprivation, costly fertilizers, pesticides and many more needs to continue the agriculture. These made to lose the interest on agriculture and almost all started earning through non agricultural fields and left their lands free from crops. But from the past ten months the scenario has changed rapidly with decrease in population due to corona virus attack and people started farming during the lockdown period.

The COVID-19 pandemic period is positively impacted on the daily life style of people. The life situation made almost all to depend on digital technology. It was the only one way to know updates during the time and learn something new. The people started planning to grow some crops in left over land rather sitting simply at home. Even the employees of different sector became farmers for time being. People engaged with watching farming techniques, exchanging their ideas with neighbours and other friends. The level of communication was increased through different channels. Apart from that through different media we could find the problems faced by the farmers of different area. Many suicide cases of farmers also have been observed due to the different reasons related to agriculture.

\section{Contribution of agriculture to the Indian economy}

Agricultural productions are contributing immensely to the development of India's economy. In current situation, India is recognized as one of the world's largest agricultural production country. Decades ago number of changes had been taken place such as organized sectors, contract farming, mechanized agriculture, easy loans, export facility, use of agrochemicals, high yielding seeds, role of private sector branding and marketing etc. The need of Agricultural product is more in India due to the largest population. More than $50 \%$ of Indians are agriculturist and this promoted the agricultural market. Since 5 years the growth of
Gross Domestic Product (GDP) shows that rise in the disposable income of consumers, this has driven the rise of income of both producer and consumer. This progress allowed the farmers to invest more. Different countries started growing huge quantity of cereals, fruits, vegetables, flowers etc. The Indian government's support is critical to the advancement of the agricultural sector. Subsidies, provision of seeds and saplings, equipments etc are provided by the government. Modern retail is helping the formers; this will eliminate middlemen and help to get reasonable prices for the producer [3].

\section{Modern technologies and use of it in agriculture}

Technology is playing a vital role in every commercial form; it helps to both producer and consumer. In India core sector for the food security is agriculture which also provides nutritional security to sustainable development and poverty elevations. Around $64 \%$ of total labor depends on agricultural business [4,5]. Farmers should take advantage of the technological revolution to boost their farming and livestock-rearing yields. The quality of Planting and growing techniques of agricultural field increased the reformers efficiency and maximized the yield [1,2]. Smart farming in India is transforming the face of agriculture by incorporating new digital technology such as sensors, location data derived from the Global Positioning System (GPS) and satellites, robotics, and analytics. The advantages of modern technologies are as follows.

1. The tractor, in combination with new tillage and harvesting machinery, irrigation, and air seeding technology, would result in higher yields of higher quality [11].

2. Smart phones are increasingly being used to track and automate crop irrigation systems. Cameras set up properly around the farm will send photos back to a central location, such as an office or a home computer. When the farmers are at home for the night or abroad, this allows them to keep a closer eye on the animals [11].

3. Moisture sensors in the field would be able to tell you how much moisture is present at different depths in the soil [11].

4. Ultrasounds for livestock are used to monitor babies in the womb and to determine the 
quality of meat in an animal before it is sold [11].

5. Crop Sensors can aid in the efficient application of fertilizers as well as increased uptake. Based on the amount of light reflected back to the sensor, optical sensors may determine the amount of fertilizer a plant can need [11].

6. Sector mentor for Soils is an app that helps to monitor the health of soils on farm. Agronomy- the science of soil management is used to increase the agriculture production. The Permaculture Association has created a series of very simple soil tests that don't require any special equipment or training [12].

7. Deep learning- it is a technology gives a significant data to farmers to check soil health, animal health, getting guideline, right financial aid, and suitable government schemes. [3,4]

8. Indoor vertical farming - It's a method of growing produce in a closed, regulated environment by stacking it one on top of the other. When compared to conventional farming, it needs less land, allowing even poor farmers or formers with limited land access to the system, as well as reducing the effect of farming on the environment. Indoor vertical farming is often correlated with urban and city farming though it thrives in limited space. This method maximizes the crop yields and meanwhile reduces labor costs. Vertical gardening is unusual in that it allows plants to flourish without the use of soil in some cases. Vertical farms use up to $70 \%$ less water than conventional farms and use artificial glow lights instead of sunlight [10].

9. Block chain - Block chains are a decentralized framework that guarantees validated goods and practices in order to establish a transparent market for quality products. Its ability to monitor ownership records and resist tampering can be used to address emergency problems in the current food system, such as food theft, safety recalls, supply chain inefficiency, and food traceability. Block chains can be used to track a food item's journey from farm to table in real time. It also adds value to the existing market by adding a ledger into the network and automatically matching market prices. [10]
10. Artificial Intelligence - New data opportunities arose as a result of the growth of digital agriculture and related technologies. Satellites, remote sensors, and Unmanned Aerial Vehicles (UAVs), also known as drones, can collect data over an entire field 24 hours a day and track plant health, soil quality, temperature, humidity, and other factors. The concept would assist farmers in better understanding the state of their fields, allowing them to make better decisions in order to achieve their target of a better harvest [10].

\section{Indian government initiatives to raise the agriculturists}

1. Tribal marketing development Federation is initiated by government of India in 2020 for the encouragement of production of hundred new forest fresh Organic products sources from tribes.

2. The National Bank for Agriculture and Rural Development planned a subsidy for agricultural and rural development (NABARD).

3. Along with the land record details Pradhan Mantri Fasal Bima Yojana (PMFBY) and soil health card will be integrated through a common database.

4. Pradhan Mantri Matsya Sampada Yojana (PMMSY), e-Gopala App and several initiatives in fishery diary, animal husbandry and Agriculture also launched by central government.

5. Animal Husbandry Infrastructure Development Fund (AHIDF) was launched by the central government along with National Animal Disease Control Programme (NADCP)

6. Digital Technology was issued by the government.

7. Pradhan Mantri Krishi Sinchai Yojana (PMKSY) is launched by the central government

8. The Indian government intends to triple the ability of the food processing sector by enabling $100 \%$ Foreign Direct Investment (FDI) in food marketing and e-commerce.

9. To establish a single national market for agricultural commodities, the government launched the electronic National Agricultural Market in 2016.

Within the few years India is expecting to 
double the farmers' income by genetically modified crops [1]. Along with this several policies are established by the Indian government to uplift the agriculture over the globe.

\section{Problems faced by the rural area farmers by infiltrate of modern agro techs}

Agricultural community is having a lot of difficulties. The technology granted easy methods to get high quantity products with high income for the agriculturists. A lot of improvement has done in agricultural field but small scale agriculturists and Middle scale agriculturists are depend on the traditional techniques like natural water irrigation groundwater river rain, ordinary food for cattle, usage of organic fertilizer to the plants etc [4]. Changes are good to yield high productivity but the poor farmers having less cultivation land and they could not find worth to utilize the technologies utmost. Technology has brought up to save the time and completes the work with minimum number of workers. These lead workless days to senior labors those who couldn't catch up the techniques and remained as unskilled. As the technology increased the field workers who knew traditional methods of agriculture started turning towards the technology dependent family as they will get less work. The land is small means the less number of labours to work and it is not worth to purchase required machineries, costly fertilizers and pesticides, usage of irrigation methods, materials required for fence and many more alternates. On the whole technology made poor farmers to struggle for the workers as the price of machineries are not affordable and it's not worth to use for small scale farming. Additionally the other issues observed of the small scale agriculturists are as follows.

- The labors who knew to work based on established ways won't be ready to come though they started earning more in non agricultural fields by the influence of technologies or they may feel lazy to work alone in work area. Due to this the rich farmers started hiring the labors by giving excess money. The field workers also took advantage of it by demanding for more wages, luxury food, drinks and many more. So, poor farmers cannot fulfill the demands of the workers. Some of the poor formers gave up the agriculture because of not getting workers.
- If the small scale agriculturist are ready to hire the machineries, the owners of these may reject as it is not benefited and its waste of effort. In reality even though farmers spend money for hiring machineries and required materials, the yield will not give profit; in fact income will be less than the spent money.

- Even though the food products gained by the less land farmers will be used only for the house managing purpose, the yield is not enough for the entire year. Shortage of food items making them to buy from the market.

- The cultivation land may be far from the living area of farmer. This troubles the farmer in each step of farming. For each and every purpose travelling near the field, varying weather conditions, exposing to the environment may make farmers to lose their interest in agriculture.

- Safe guarding the yields by the wild animals plague is a biggest task for the farmers.

- Higher education level of farmer's children may attract them towards modern technologies over traditional method of farming. Children may think only about the productivity of crops by ignoring remaining complications.

- The traditional method of farming may avoid an additional expense and usage of technology will be costly.

- Getting technicians to repair damaged machineries will be difficult. Technicians shop may not be nearby. If the service men have to come from far places they should be paid extra. For the small repair works technicians may not agree to come and sometimes they may ask the farmers to get the machines near to them.

- Chemical fertilizers may be costly to buy for an ordinary farmer or poor farmer. The less land holding farmer may not buy the fertilizers by thinking about cost, yield profit at the end. Because of the lack of fertility in soil it may require much fertilizers and yield may vary. Land will be losing its fertility power by changing the fertilizers.

- Rural area formers might have not aware of better quality pesticides to protect their crops.

- Poor farmers may not have vehicles to transport the grown products to get good market value from the traders. Nearby traders may give less value to the products. So farmers 
get loss by selling the products to nearby traders.

- Most of the small scale agriculturist does not have regular customers. Either the product will remain or this may lead the mediators to make money and traders will get more profit.

- Small scale agriculturists may not get marketing for their products though the products may not be regular to the market. Farmers may change the crops to check the fertility of the crops in their land.

- Whenever the small scale agriculturist get good yield, they may not get good rate in market. Price may vary and farmers may not get the satisfactory marketing value.

- Agriculturists may find difficult to communicate effectively with the mediators, traders or with the customers. They may fail to attract the customers directly or they may vary their price as per the communication of mediator/trader/customer.

- Lack of information regarding the updated machineries to the farmers keeps them away from the advanced agro-technologies. Information technology is speed enough to reach the rural area farmers but lack of awareness about the same has made formers to be less confident to follow up. The farmers of rural area don't get the proper information even from the local informers.

- Farmers also face a number of challenges, including depletion of natural resources, climate change, shifting demand and consumption patterns, transitioning to highvalue agriculture, rising population pressure, and trade liberalization[6].

The slow agricultural growth in India is due to a poorly managed irrigation system and a lack of good extension services. Poor economic condition illiteracy is the root cause for the poverty of farmers. Low progress in land reforms, inefficient Finance and marketing service, inconsistent in government policy, subsidy problem, often variable in the tax are the reasons for the low production. Depending on the geographical location to increase agricultural production, a screening of technology and the local background of agriculture must be completed [7-10]. So because of these all problems farmer may leave the land empty without doing cultivation. This is a great loss to the person as well as it impacts on the economic condition of society. If most of the agricultural family think same and do same then it is a considerable loss to the nation.

\section{Suggestions}

Alternative method of farming will always secure the future of farmers. Rather being behind a single type of cultivation of crops, multi disciplinary farming can be adopted. Along with the different crop cultivation other agricultural sectors can be touched with the assistance of respective disciplines. World trade organization (WTO) is giving awareness program to farmers. It is trying to reach its message to ordinary people. Various articles of WTO displayed in different languages by experts. This is very essential to the farmers, which gives awareness to the common farmer too. Government policies on tariff, imports, impact of various subsidiary schemes done with concern. These relaxations helped lot to the Indian Agriculturists [5]. Farm Hack is an open-source website where farmers and growers can share information about low-cost, low-tech solutions they've built for their farms [12]. Similarly village wise, Taluk wise or district wise farmers meet can be organized to share the problems and to discuss the solutions. Attending of informative workshops, training programs related to agriculture will also help in overcome from certain problems.

The Indian Council for Agricultural Research (ICAR) founded Krishi Vigyan Kendra (KVK) as a multidisciplinary farm supporter for the agricultural sector. It is funded and technically supervised by ICAR and is located at the district level [6]. Digital technology is reducing difficulties in gathering the required information. So, the farmers can access the information regarding various agricultural sectors, financial benefits such as agricultural subsidies, loans easily once after approaching KVK or any other respective guides and details can verified with the experienced farmers too to avoid common issues. Gaining a broad range of knowledge about production technology, harvesting processes, market access, price information, and industry is critical to increasing profits. Small scale farmer strongly needs stronger intermediaries to facilitate information access. Successful delivery of Agricultural extension will progress against poverty and hunger. Rise of global food price 
increase the benefit of the farmers [6].

Less expenditure on cultivation and gain from marginal return by the organic farming method will reduce the socioeconomic problems of poor and small scale farmers [8]. Finding most profitable farming will reduce the stress of farmers and release them from frustration. Better alternative crop solutions can be found through different channels with detail such as less water consuming crops, plantations, proper irrigation methods, high yielding seasonal crops, better quality seeds, pesticides, crops grown in wet and dry lands, the agricultural sectors which returns highly to the farmer, good quality and quantitative crops and so on. Organic farming practices contribute to agriculture's long-term viability in terms of both environmental and economic factors. Improvement of socioeconomic level of small and poor farmers will reduce farmers' suicides in India [1-4]

\section{Conclusion}

The Industrial Revolution, which saw the introduction of agricultural machinery to mechanize agricultural labour, resulted in a significant increase in farm worker productivity. Along with Government initiatives, agricultural related departments are encouraging the farmers in many ways. Besides, Digital technologies can especially improve the lives of farmers and agricultural workers. Utilization of Digital agriculture to access useful information could revolutionize the farmers' communities to secure their livelihoods in current scenario. Millions of farmers can benefit from the acquisition of realtime farm information in the near future as a result of widespread adoption of modern agriculture. While it is difficult to forecast the future of agriculture technology, there are numerous pilot projects and encouraging patterns.

Artificial farming can't save the future of living beings but adaptation of smart farming will bring down the difficulties of farmers in present era and empowers them. So, the natural agriculture with acceptable suggestions and solutions will be ever green and farmers' contributions always appreciable.

\section{Acknowledgement}

I am very grateful for the timely guidance, constant support given by Mrs Hemalatha B D, Research scholar, Department of Political Science,
Mangalore University, Mangalagangothri. I wish to extend a heartfelt thanks to my better half $\mathrm{Mr}$ Naveen Acharya for his encouragement and suggestions. The assistance provided by $\mathrm{Mr}$ Dinesh was greatly appreciated. I would like to thank all my family members for their support.

\section{References}

[1] Agriculture and Technology in India Reference to small farmers, Problems and benefits, www.ibef.org/industry/agricultureindia.aoex-link, Indian agriculture and allied industries, Industry report (2020) November.

[2] Linly $\mathrm{Ku}, \mathrm{New}$ Agriculture Technology in modern farming, www.plug and play tech enter.com/resource/new

[3] www.imaregroup.com/agriculture-industry-inindia

[4] Priyadilani, "Technology and agricultural field in www.analyticsinsighht.net/technology-

can benefit- Agriculture India latest news, (2020) October 21.

[5] Mittal S C, "Role of Information Technology in agriculture and its scope in India", (2001) Fertilizes news-46(12),83-88

[6] Claire J. Glendenning, Suresh Babu, Kwadwo Asenso-Okyere- "Review of Agricultural Extension in India Are Farmers' Information Needs Being Met?", IFPRI Discussion Paper 01048, (2010) December.

[7] Nidhi Dwivedy , "Challenges faced by the Agriculture Sector in Developing Countries with special reference to India"

[8] Karthikeyan Mariappan, Deyi Zhou, "A Threat of Farmers' Suicide and the Opportunity in Organic Farming for Sustainable Agricultural Development in India", (2019) April 23.

[9] https://en.wikipedia.org/wiki/Agricultural_tech nology\#: :text=A\%20major\%20turning\%20po int $\% 20$ for, greatly $\% 20$ increasing $\% 20$ farm $\% 20$ worker\%20productivity.

[10]https://www.plugandplaytechcenter.com/resou rces/new-agriculture-technology-modernfarming/

[11]Nidhi Sharma, Amit Kumar Mungarwal, "It is possible to monitor and control the irrigation of crops through a smart phone", (2019) August 05

[12]https://www.downtoearth.org.in/blog/agricultu re/applying-modern-tech-to-agriculture-66017 